\title{
衝突噴流熱伝達と光の流れ挙動に及ぼすオリフィス形状の影響*
}

\author{
金森 梓*1，檜和田 宗彦*1，瀬名波 出 $*^{2}$, 親川 兼勇*2

\section{Effect of Orifice Configuration on Flow Behavior and Impingement Heat Transfer}

\author{
Azusa KANAMORI*1 ${ }^{*}$, Munehiko HIWADA, Izuru SENAHA and Kenyu OYAKAWA \\ *1 Gifu Univ., Dept. of Mechanical and system Engineering \\ 501-1193, 1-1, Yanagido, Gifu, Gifu, Japan
}

\begin{abstract}
Impingement jet is widely used in industrial fields because it provides a high heat transfer coefficient near the stagnation region. However, few methods exist to control the impingement heat transfer. Recently, peculiar diffusion process "axis-switching" in three dimensional free jet has been reported, and the possibility of axis-switching controlling the diffusion and mixture process has begun to attract attention. In this report, we have studied experimentally the effect of the orifice configuration on the impingement heat transfer using non-circular orifices. In addition, "axis-switching phenomenon" was showed clearly by the flow visualization using the hydrogen bubble method. Orifice configurations are the regular polygons with 3 to 6 sides. Heat transfer experiments covered the distance between the orifice-to-target plate is 4 to 8 and Reynolds number is $5 \times 10^{4}$ and the constant heat flux is $600 \mathrm{~W} / \mathrm{m}^{2}$. The flow was visualized in Reynolds number 1,500. In the free jet from the regular polygon orifice, when the number of sides on the orifice increased, the occurring location of "axis-switching phenomenon" moved towards the orifice exit and the tendency of the iso-Nusselt number profile became the concentric profile upstream. With the decrease in the number of sides on the orifice, the iso-Nusselt number profile after "axis-switching phenomenon" was kept at the downstream.
\end{abstract}

Key Words : Jet, Flow Visualization, Vortex, Forced Convection, Impingement Heat Transfer

\section{1. 緒言}

噴流 ${ }^{(1)}$ ( (3) は自然現象や工学的な分野で見られる代表的な流れの形態であり, 工学的分野では加熱, 冷却, 乾燥混合, 化学反応, 燃焼, 噴霧など実用広範に用いられるとともに, 拡散や騒音など工学的諸問題点とも深い 関わりを持った重要な流れの一つである. その中でも衝突噴流は, よどみ点近傍において高い熱伝達率を与える ことが古くから知られており, さまざまな物体の加熱, 冷却, 乾燥や物体表面の污れ, 水分除去などにおける有 効な技術として広範囲で使用されている. 一例を挙げれば, 電子機器やガスタービンのカスケードの冷却, 䋊維 や高分子フィルムの乾燥, 高硬度材の仕上げ加工や表面改質といった多くの工学的応用を担っている. また, 近 年の省エネルギー化, 機器のコンパクト化の観点からも, 衝突噴流の流動及び熱・物質伝達特性を明らかにし, 改善・向上させることは重要であり, 有効的に衝突熱伝達を制御寸るために, 現在でもなお精力的に研究が行わ れている，噴流制御方法には，噴流出口へのタブの設置や旋回噴流の利用といったような受動的制御と，噴流外 部から音場や速度変動を加えるような能動的制御がある. その中で最近, 受動的制御方法の一つとして非円形噴

\footnotetext{
* 原稿受付 2010 年 8 月 20 日

*1 正員, 岐皁大学（干501-1193 岐阜県岐阜市柳戸 1-1）

*2 正員, 琉球大学 (广903-0213 沖縄県中頭郡西原町千原 1 番地)

E-mail: hiwada@gifu-u.ac.jp
} 
流 ${ }^{(4)}$ ～(6) を使用したものが注目されている. 非円形噴流の特徴として axis-switching 現象と呼ばれる, 噴流の長 軸方向と短軸方向が入れ替わる，すなわち噴流断面形状の方向がスイッチ寸る現象がある，axis-switching 現象は 流れ方向の特定位置で起こるが, axis-switching 現象の起こる位置と回数は噴流の出口形状に大きく依存すること がわかっている。このような特異な拡散過程を持つ現象の利用により，新たな制御の可能性が生じている。これ

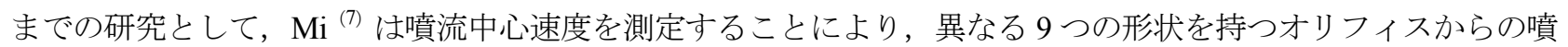
流拡散過程を明確にした. 檜和田 ${ }^{\left({ }^{8}\right)}$ は音場を励起した楕円形オリフィス衝突噴流においてオリフィスのアスペク ト比が熱伝達特性に及ぼす影響を調べた. さらに近年の研究としては, Quinn ${ }^{(9)}$ は二等辺三角形オリフィスを使 用し，オリフィス近傍での平均流量と乱流特性の実験を行った. また Chaudhari ${ }^{(10)}$ は正方形, 円形, 長方形オリ フィスを用いて，衝突噴流冷却に及ぼすオリフィス形状の影響を調べた.

本論文では，正三角形，正方形，正五角形，正六角形の 4 つ非円形オリフィスを用いて，自由噴流挙動に及 ぼすオリフィス形状の影響を，水素気泡法による可視化によって明らかにした。さらに衝突噴流において衝突熱 伝達特性に及ぼすオリフィス形状の影響を実験的に検証し, オリフィス形状による衝突熱伝達制御の可能性につ いて調べた.

\section{2. 実験装置及び実験方法}

\section{$2 \cdot 1$ 自由 $\cdot$ 衝突噴流特性}

本研究で使用した実験装置を図 1 に示寸。空気はブロワーにより送り出され，整流部を通り，オリフィスから 噴出された. 図 2 に本実験で使用した座標系を示す. 主として直交座標系を用いており，オリフィス重心点を原 点にとり，オリフィス重心線上である噴流中心軸線方向を $x$ 軸とし，それに直交する噴流断面に $y, z$ 軸をそれぞ れとった，オリフィスの底辺側と頂角側では噴流出口において速度分布が異なっており，噴流の広がりがオリフ ィスの底辺側と頂角側では異なるため, オリフィス重心から頂角方向に $y_{a}$ 軸, 底辺方向に $y_{b}$ 軸をとった. 表 1 に オリフィスの形状と詳細寸法を示寸.オリフィス形状は正 $n$ 角形と円形とし, 正多角形オリフィスは辺の数 $n=3$, 4, 5，6の, 正三角形, 正方形, 正五角形, 正六角形とした. オリフィスは, 厚さ $1 \mathrm{~mm}$ の真鍮板をワイヤカッ 卜加工で制作し, 逃げ角は $0^{\circ}$ である. 各オリフィスは面積が等しくなるようにし, 等価直径は $D_{e}=51 \mathrm{~mm}$ とし た.レイノルズ数は $R e=5.0 \times 10^{4}$ 一定で, 代表長さを $D_{e}$, 代表速度を $\mathrm{I}$ 型熱線流速計で測定した噴流出口速度 $U_{0}$ とした.

自由噴流特性は, 自由噴流流れ方向のある断面 $x / D_{e}$ での, 平均速度分布 $U_{m} / U_{0}$ と乱れ強さ $T_{u}$ として表した. ここで $U_{m}$ は自由噴流の各 $x / D_{e}$ における $x$ 軸方向の最大速度である. 乱れ強さ $T_{u}$ は, $U_{m}$ の時間変動データを二 乗平均した $U_{r m s}$ と， $U_{0}$ により次式のように定義した.

$$
T_{u}=\frac{U_{r m s}}{U_{0}} \times 100
$$

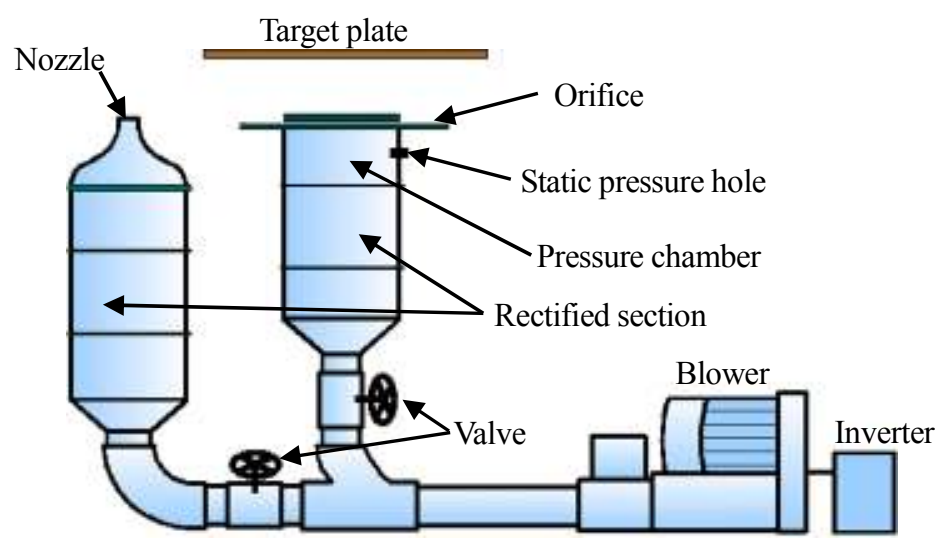

Fig. 1 Experimental apparatus of free and impingement jet 
衝突噴流特性は, オリフィスと平板の間隔 $L / D_{e}$ における壁面平均圧力係数 $C_{p w}$ と局所ヌセルト数 $N u$ で表した. $C_{p w}$ は次式で表され，ここで, $\rho$ は空気密度, $p$ は $0.02 \mathrm{mmAq}$ の感度がある精密微差圧力計で測定した平板上の静 圧である.

$$
C_{p w}=\frac{2 p}{\rho \times U_{0}^{2}}
$$

静圧測定用の平板は $700 \times 700 \mathrm{~mm}$ のアクリル樹脂でできており, 直径 $0.8 \mathrm{~mm}$ の圧力孔が 71 個，異なる間隔 で，平板中央に十字状に空けられている．データの測定は，オリフィスと平板の中心を噴流中心軸線上に合わせ 実施した. 熱伝達率は, $600 \times 600 \mathrm{~mm}$ のベークライト板に厚さ $20 \mu \mathrm{m}$ のステンレス箔を貼付し, 通電加熱するこ とにより測定した．ステンレス箔は熱損失を最小限にするために 5 枚に分割されており，直列に $6 \mathrm{~A}$ が通電され た．衝突平板の裏側を断熱材で覆うことにより，衝突平板裏面への熱損失は伝熱・ふく射ともに無視できるとみ なし, 熱流束 $q=600 \mathrm{~W} / \mathrm{m}^{2}$ を確保した. 平板表面温度 $T_{w}$ はステンレス管の裏側にはんだ付けされた 38 個の $\mathrm{Cu}-\mathrm{Co}$ 熱電対を用い, オリフィスと平板の位置関係を $C_{p w}$ 測定時と同様にして測定した. これらの熱電対を $1 \mu \mathrm{V} の$ 感度 を持つ $\mathrm{AD}$ 変換器に接続し, データはパーソナルコンピューターで収集され, 熱電対によって測定した局所温度 から局所ヌセルト数 $N u$ を次のように算出した。 ここで $\lambda$ は空気の熱伝導率, $\alpha$ は局所熱伝達率, $T_{0}$ は噴流出口温 度であり $T_{w}$ と同様に Cu-Co 熱電対を用いて測定した。

$$
N u=\frac{\alpha D_{e}}{\lambda}=\frac{q \times D_{e}}{\lambda\left(T_{w}-T_{0}\right)}
$$
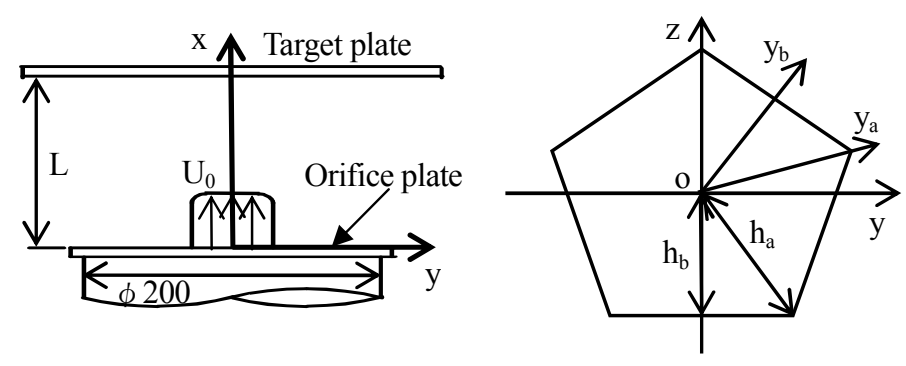

Fig. 2 Coordinate system

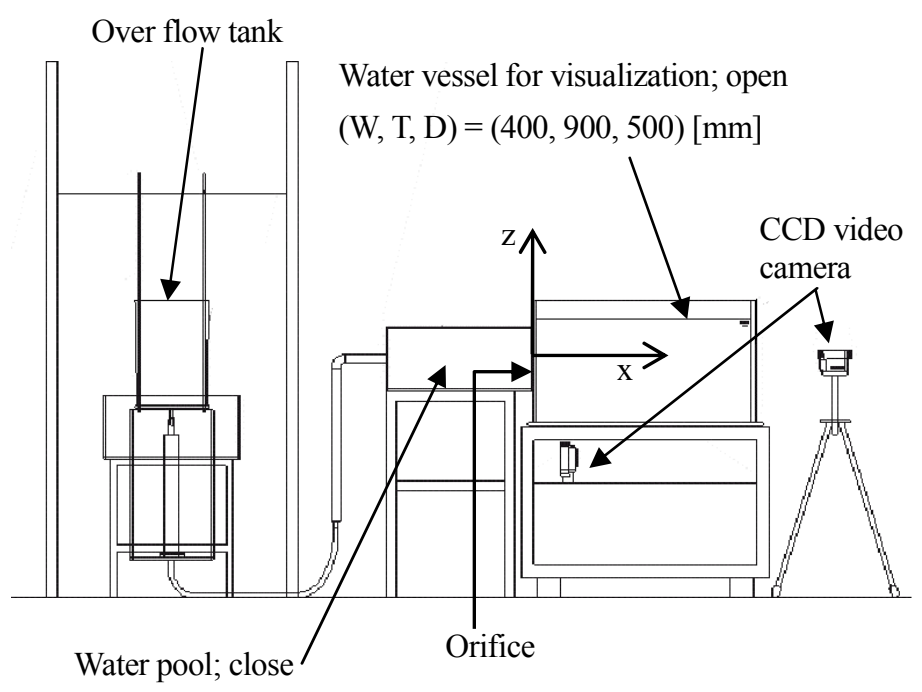

$(\mathrm{W}, \mathrm{T}, \mathrm{D})=(250,530,280)[\mathrm{mm}]$

Fig. 3 Experimental apparatus of flow visualization

Table 1 Orifice configuration

\begin{tabular}{|c|c|c|c|}
\hline Configuration & $\mathrm{n}$ & $\mathrm{h}_{\mathrm{a}}[\mathrm{mm}]$ & $\mathrm{h}_{\mathrm{b}}[\mathrm{mm}]$ \\
\hline Triangle & 3 & 39.7 & 19.8 \\
\hline Square & 4 & 32.0 & 22.6 \\
\hline Pentagon & 5 & 29.3 & 23.7 \\
\hline Hexagon & 6 & 28.0 & 24.3 \\
\hline Circle & - & 25.5 & 25.5 \\
\hline
\end{tabular}

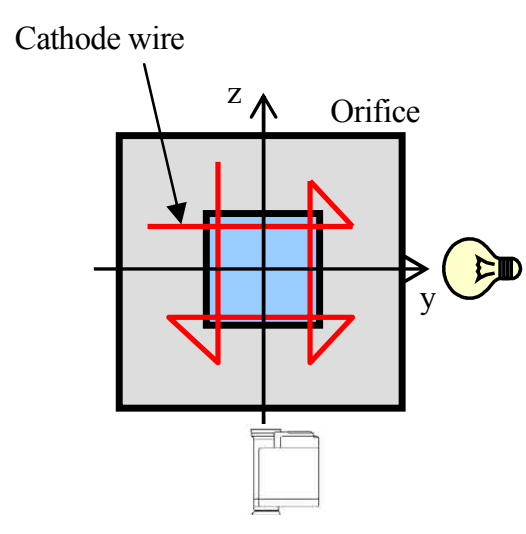

CCD video camera

Fig. 4 Cathode wire setting 


\section{$2 \cdot 2$ 流れの可視化方法}

図 3 に水素気泡法を用いた可視化の実験装置, 図 4 にオリフィスへの陰極線セット方法を示寸. 2 つの CCD カ メラは同時刻に $x-y$ 平面と $y-z$ 平面の画像を撮影寸るために用い, 1 フレームを $1 / 30 \mathrm{sec}$ とした. 光源は 2 つのカ メラに垂直方向の $y$ 軸方向から照射できるよう配置した. $U_{0}$ は約 $0.05 \mathrm{~m} / \mathrm{s}$ であり, $R e=1500$ である. 陰極線には 直径 $70 \mu \mathrm{m}$ のコンスタンタン線を使用し, オリフィス内側のエッジに設置した. axis-switching 現象が生じると, オリフィス出口で形成された渦が $y-z$ 平面上で変形すると同時に, $x$ 方向の相対速度が変化する. 渦の変形は噴流 外縁の局所曲率が大きい部分から始まり, 変化した部分の $x$ 方向の速度は変化していない部分の速度に比へ速く なる. 結果的に $y-z$ 平面の大きく変形した部分は $x-y$ 方向の可視化画像では相対的に進んだように見える.

\section{3. 実験結果と考察}

\section{$3 \cdot 1$ 噴流中心軸線上の平均速度分布及び乱れ強さ分布}

I 型熱線流速計を用いて計測した噴流中心軸線上 $\left(x\right.$ 軸線上) の平均速度分布 $U_{m} / U_{0}$ 及び乱れ強さ分布 $T_{u}$ を図 5 に示寸. 図には円形ノズルの結果も参考に示している. 正 $n$ 角形才リフィスでは, $n$ が小さくなるほど, より上 流側で最大速度の減衰が開始されたが, 減衰開始までの $U_{m} / U_{0}$ 分布及び減衰開始後の速度減衰の傾きは全ての才 リフィスでほぼ同一であり，正六角形オリフィスの場合は円形オリフィスの分布と差異は認められなかった．ま た，全てのオリフィス噴流では噴流出口近傍において，オリフィス噴流特有の縮流作用があり，噴流の断面積が オリフィスの断面積に比べて小さくなるため, $U_{m} / U_{0}$ は 1 を超える. 一方乱れ強さに関しては, 速度分布と同様 に $n$ が小さいほど最大 $T_{u}$ 值を上流側でとり，その最大值は $n$ が小さいほど大きくなった．また, $U_{m} / U_{0}$ 分布にお いては正六角形と円形オリフィスの場合で差異はなかったが, $T_{u}$ 分布では最大 $T_{u}$ 值をとる位置, 值ともに異なり, 正六角形オリフィスのほうが上流側で最大 $T_{u}$ 值をとり，その值は小さくなった.

図6に典型的な例として, 正三角形オリフィスと円形オリフィスのある特定の $x / D_{e}$ における $U / U_{0}$ と $T_{u}$ の分布を示す. 図の右側が $y_{a}$ 軸（頂角側）方向, 左側が $y_{b}$ 軸（底辺側）方向の分布であり, オリフィスの頂角位置 $\left(h_{a}\right)$ が点線, 底辺 位置 $\left(h_{b}\right)$ が一点鎖線でそれぞれ描かれている. 正三角形オリフィスにおいて, $x / D_{e}=0.1$ における $h_{a}$ 付近と $h_{b}$ 付近の 速度勾配は大きく異なっており, 頂角近傍の速度は著しく遅い. また, オリフィス中心付近の速度はオリフィスエッジ 付近に比べ遅く, 収縮していることが確認できた. $U / U_{0}$ 分布の広がりに着目寸ると $x / D_{e}=0.1$ では $y_{a}$ 方向に広がって いるが，噴流が下流に行くにつれ $y_{a}$ 方向よりも $y_{b}$ 方向へ広がっていった. この $0 \leqq x / D_{e} \leqq 2$ において確認された $y_{a}$ 方向と $y_{b}$ 方向の広がりの逆転は axis -switching 現象によるものである.

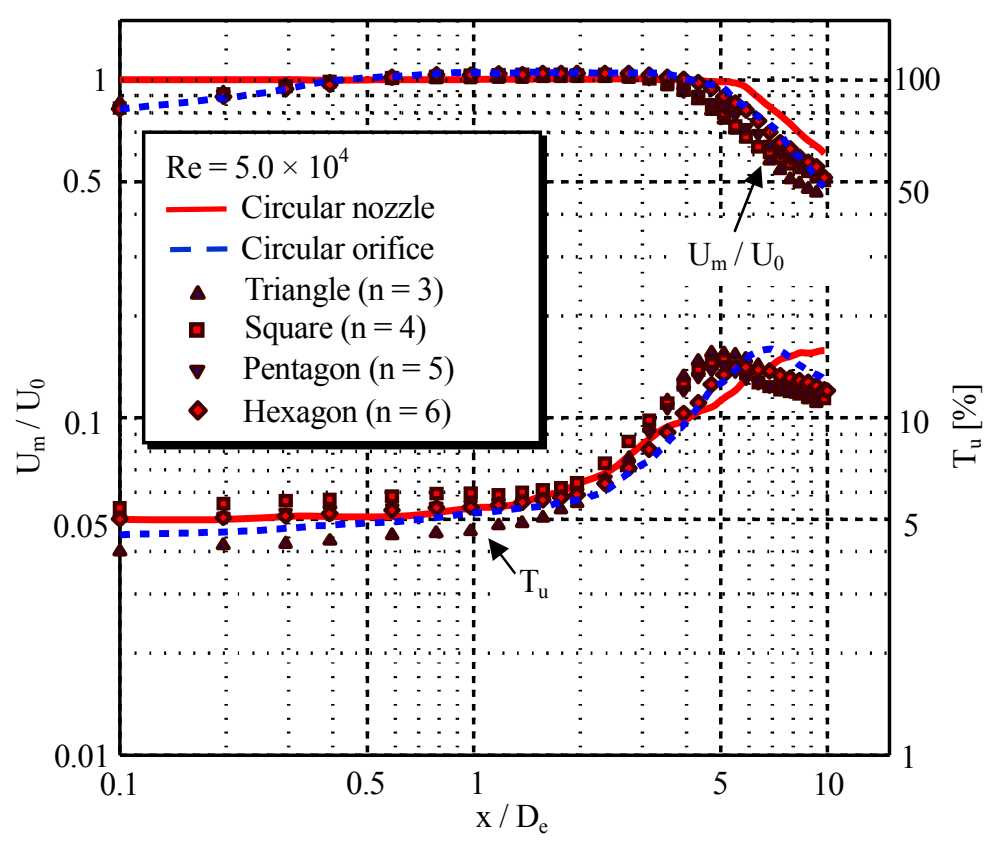

Fig. 5 Maximum velocity delay and turbulence intensity 


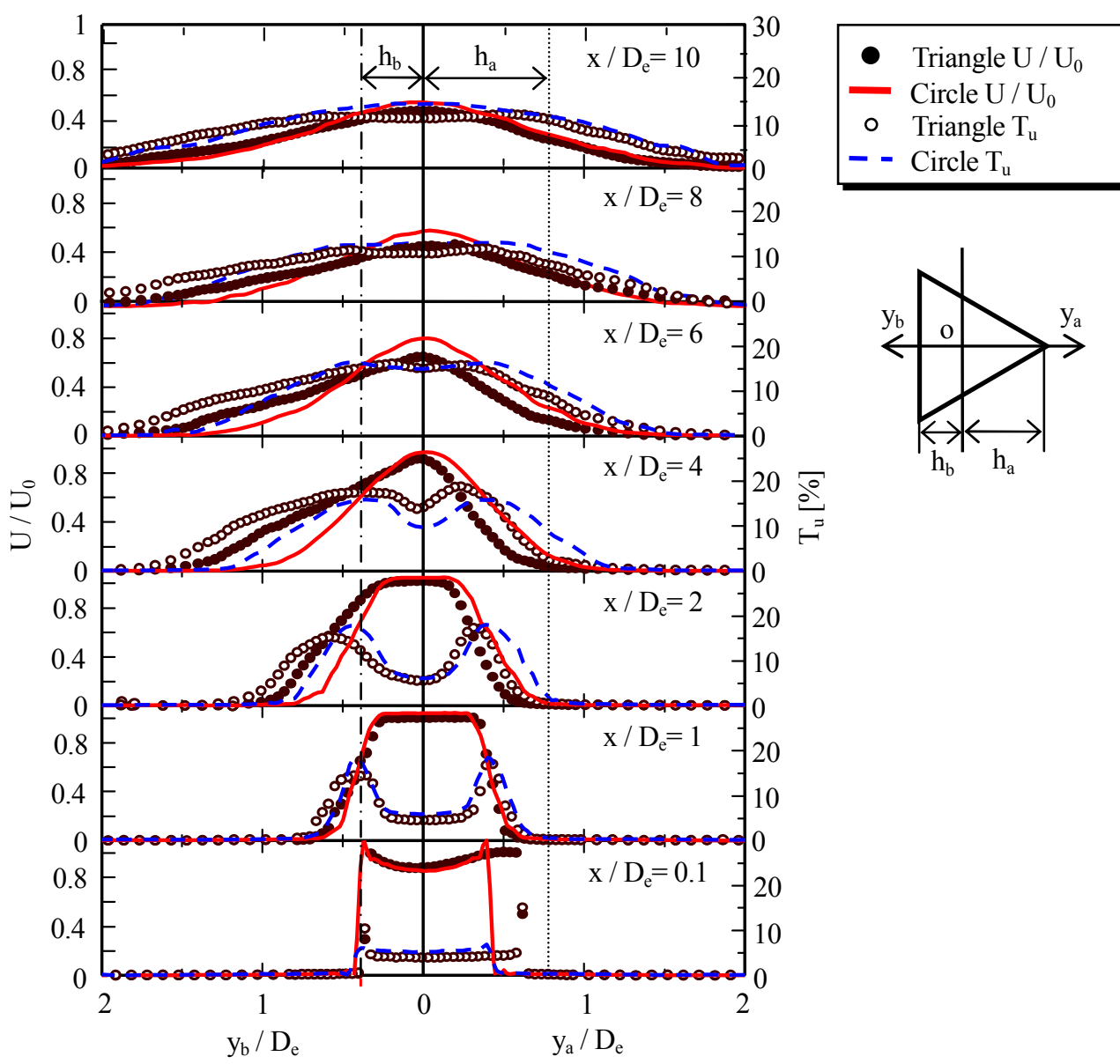

Fig. 6 Velocity and turbulence intensity profile for regular triangular orifice in $\mathrm{Re}=5.0 \times 10^{4}$
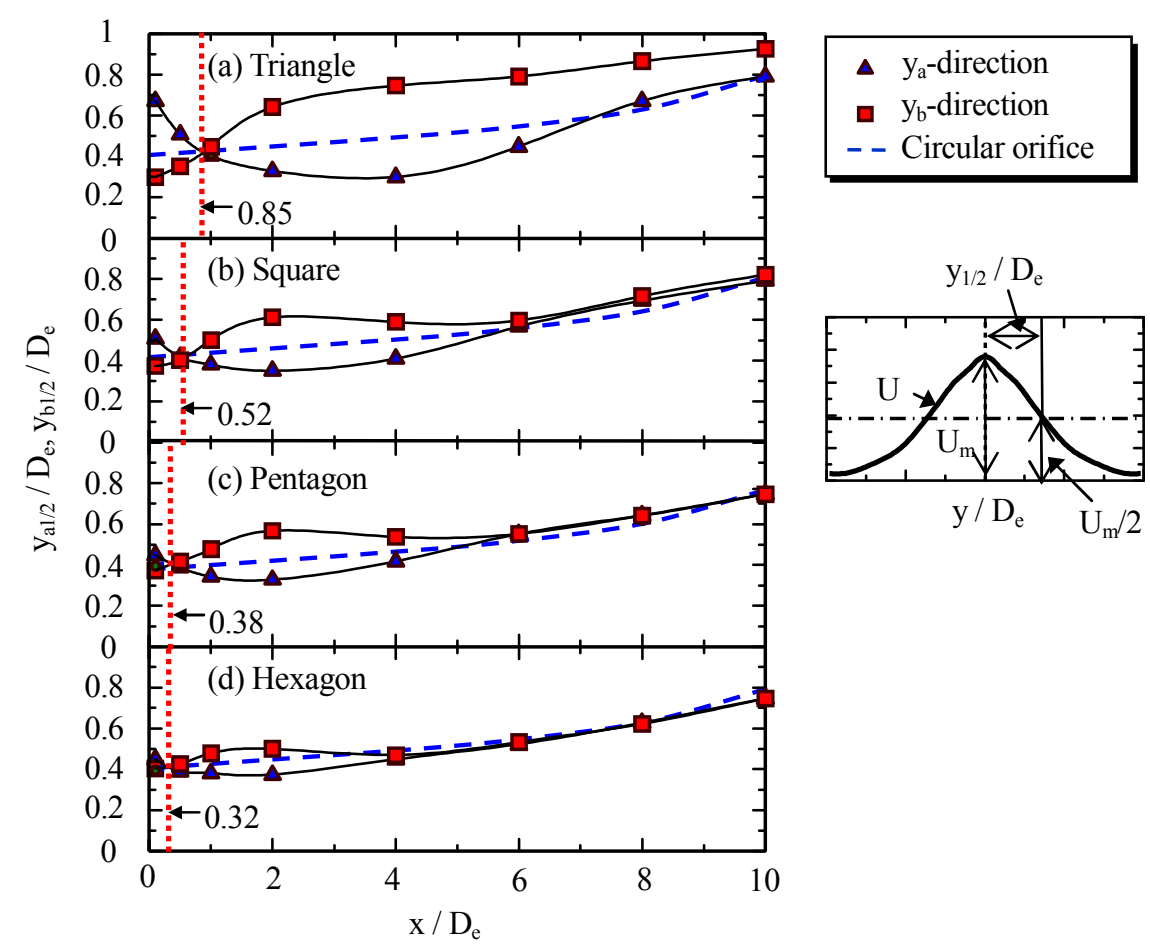

Fig. 7 Velocity half-width in $\mathrm{Re}=5.0 \times 10^{4}$ 
axis-switching 現象は正三角形オリフィスに関して顕著な現象であるが，全ての正多角形オリフィスにおいて確認 された. さらに下流部では $y_{a}$ 方向と $y_{b}$ 方向の $U / U_{0}$ 分布の差異は小さくなり, 円形オリフィスの $U / U_{0}$ 分布に近 づき, $x / D_{e}=10$ ではほぼ等しくなった. また, 円形オリフィスでは $0 \leqq x / D_{e} \leqq 4$ の範囲で最大速度が残って おり、ポテンシャルコア領域が確認できたが，正三角形オリフィスではポテンシャルコア領域が $x / D_{e}=4$ に到達 寸るまでに消滅している. 一方 $T_{u}$ 分布では, 正三角形オリフィスでの $0 \leqq x / D_{e} \leqq 4$ における $y_{b}$ 方向の最大值 は $y_{a}$ 方向の最大值よりも小さいが, 広がりは $y_{b}$ 方向のほうが $y_{a}$ 方向よりも大きくなった.

自由噴流の流れ方向に垂直な断面における平面的な広がりの違いを明確にするために, 4 つの正 $n$ 角形オリフ イス $(\mathrm{n}=3,4 ， 5,6)$ での速度半值幅 $y_{a 1 / 2} / D_{e}, y_{b 1 / 2} / D_{\mathrm{e}}$ を図 7 (a) から（d）に示す. 破線は円形オリフィスの 速度半值幅を示している. $y_{a}$ 方向と $y_{b}$ 方向の $U / U_{0}$ 分布の広がり幅は, 図 6 からもわかるように交差しているた め, $y_{a 1 / 2} / D_{e}$ と $y_{b 1 / 2} / D_{\mathrm{e}}$ は下流のどこかで交わっている. $y_{a 1 / 2} / D_{e}$ と $y_{b 1 / 2} / D_{\mathrm{e}}$ の交点は axis-switching 現象の起こる 点として定義され, その交点をとる位置は $n$ が増えるにしたがって上流側に移動した. 全てのオリフィスにおけ る速度半值幅は，下流になるほど円形オリフィスと同様となる傾向が見られた。

$\mathrm{x} / \mathrm{D}_{\mathrm{e}}$

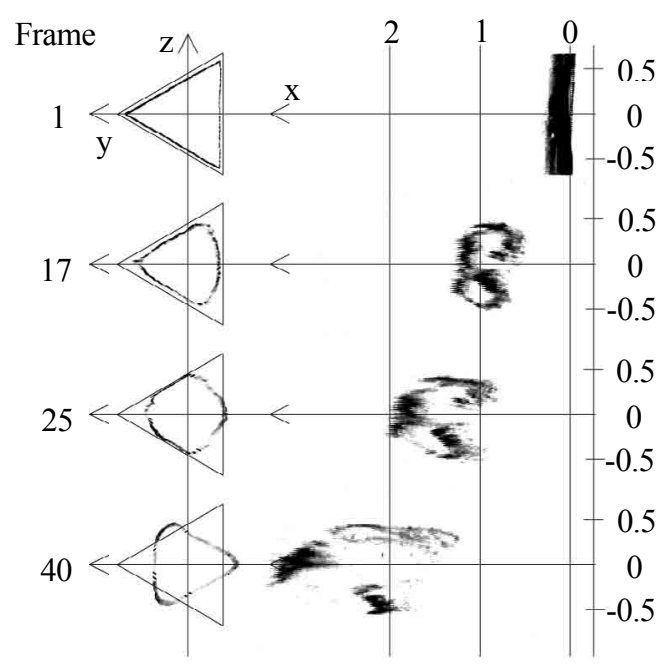

(a) Triangle

$\mathrm{x} / \mathrm{D}_{\mathrm{e}}$

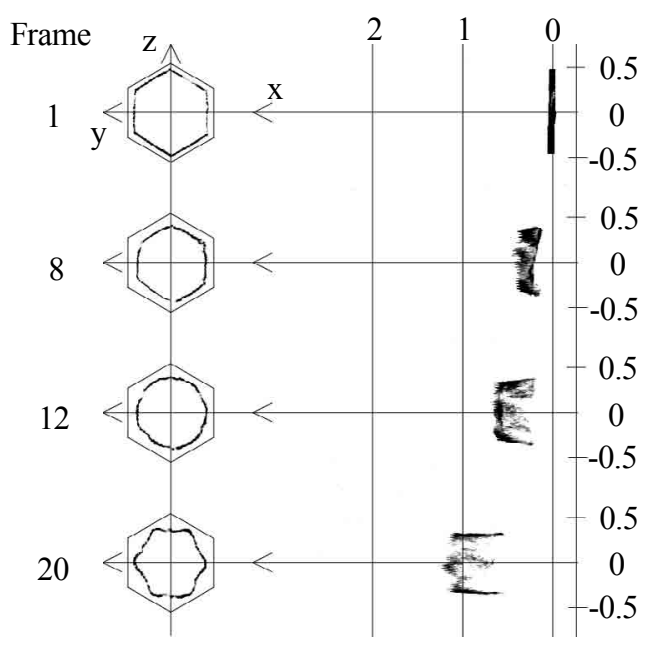

(c) Hexagon $\mathrm{x} / \mathrm{D}_{\mathrm{e}}$

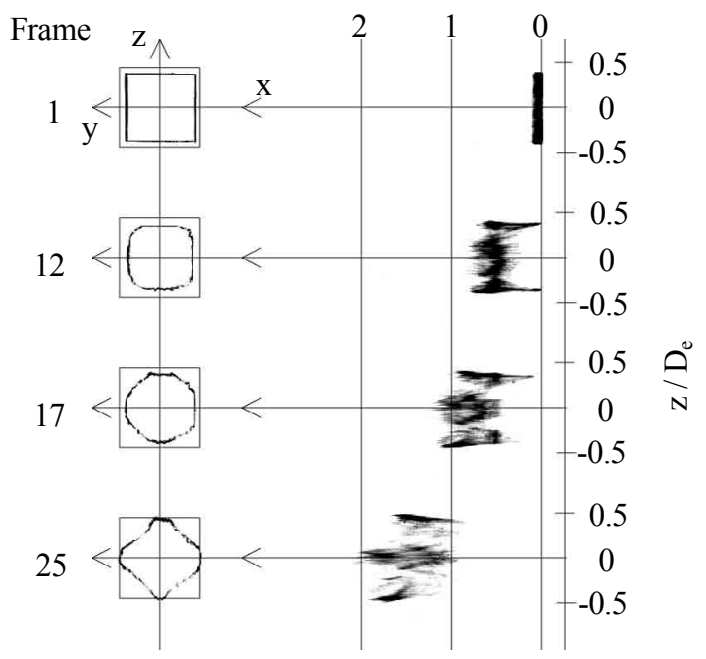

(b) Square

$\mathrm{x} / \mathrm{D}_{\mathrm{e}}$

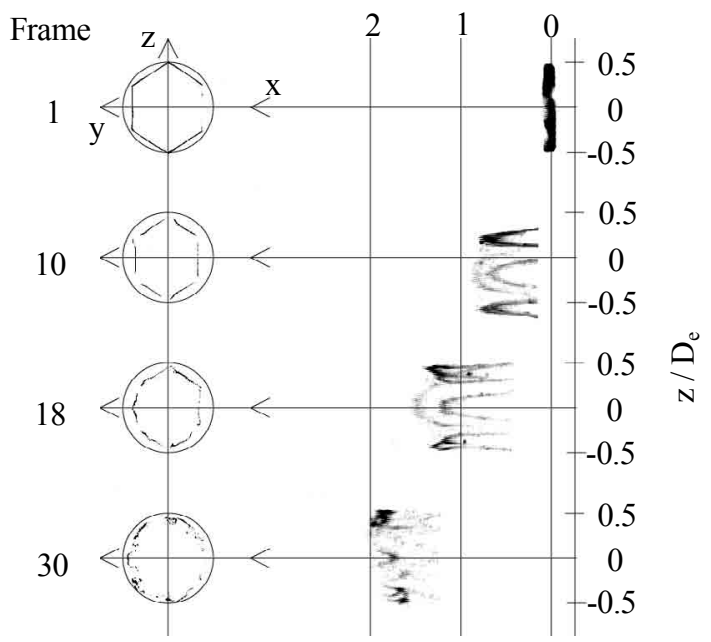

(d) Circle

Fig. 8 Flow visualization in $\operatorname{Re}=5.0 \times 10^{4}$ 


\section{$3 \cdot 2$ 水素気泡方法による自由噴流流れの可視化}

正三角形，正方形，正六角形， 円形オリフィスを使用し， $y$-z 断面と $x-y$ 断面の流れの可視化画像を図 8 (a) か ら (d) に示す。可視化画像は典型的な以下の 4 つの断面を示している. (1) オリフィス出口直後, (2) axis-switching 現象を引き起こす，最初の渦輪変形のために $y-z$ 面の渦角部が丸くなる時，（3）渦輪が $y-z$ 面でほとんど円状に見 える時, (4) axis-switching 現象が完了し， $y-z$ 面での渦形状がオリフィス形状を反転した形状となった時. 図の左 部に記載した数字は CCD ビデオカメラのフレーム数である. 全てのオリフィスにおいて, 大きな曲率をもつ頂 角側が最初に変形した，その際その面における $x$ 方向の相対速度は大きくなり，渦輪の底面側は頂角側と比べて 前方に移動する. その相対速度の違いが更なる他局所での曲率の違いを生み出し渦は変形し続け, $y-z$ 面で底辺側 と頂角側が入れ替わる.オリフィスと $y$ - $z$ 断面で観察された渦が反転した形状になった時, axis-switching 現象の 1サイクルは完了寸る. axis-switching 現象の完了寸る位置は図 7 に示すように $n$ が増加するにしたがって上流方 向に移動しており, それは可視化により確認された.
(a) Triangle
(b) Square
(c) Hexagon
(d) Circle

$\mathrm{L} / \mathrm{D}_{\mathrm{e}}=4$

$\mathrm{L} / \mathrm{D}_{\mathrm{e}}=6$
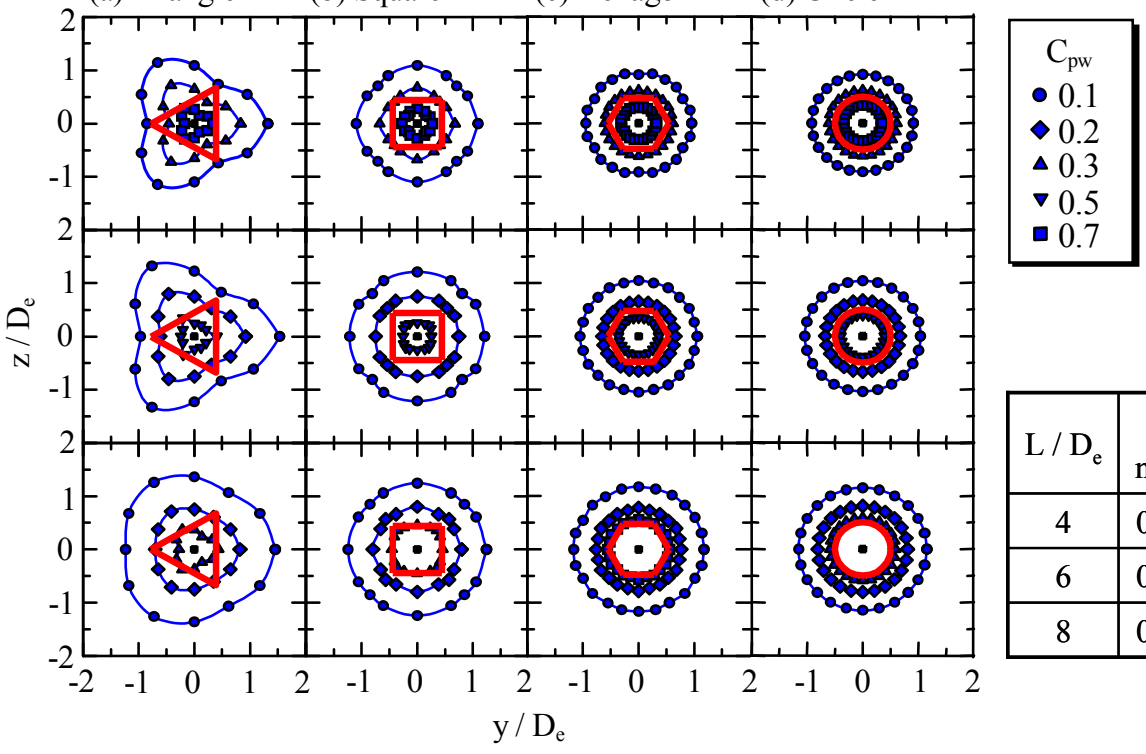

Fig. 9 Iso-local wall pressure coefficient profile on the target plate
(a) Triangle
(b) Square
(c) Hexagon
(d) Circle
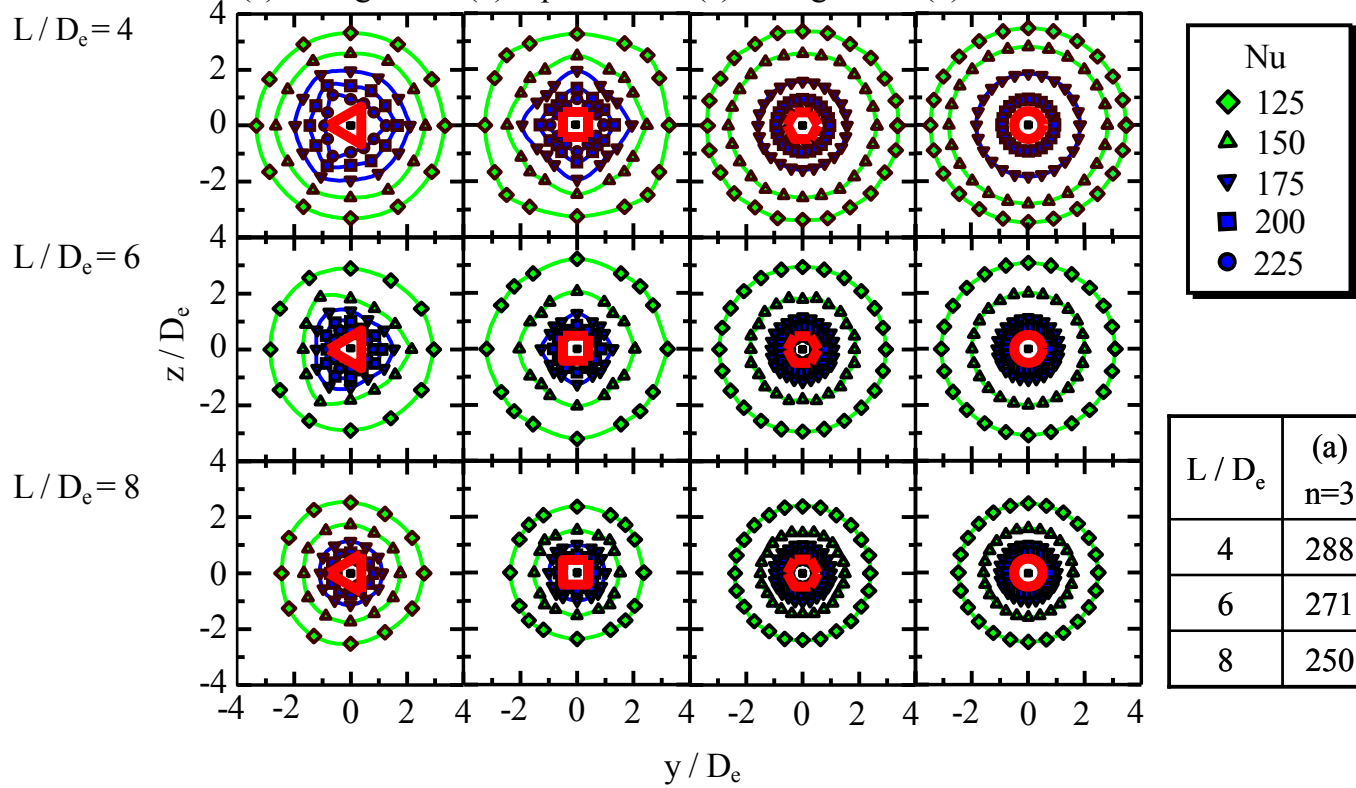

$\mathrm{C}_{\text {pw0 }}$ value

\begin{tabular}{|c|c|c|c|c|}
\hline $\mathrm{L} / \mathrm{D}_{\mathrm{e}}$ & $\begin{array}{c}\text { (a) } \\
\mathrm{n}=3\end{array}$ & $\begin{array}{c}\text { (b) } \\
\mathrm{n}=4\end{array}$ & $\begin{array}{c}\text { (c) } \\
\mathrm{n}=6\end{array}$ & (d) \\
\hline 4 & 0.92 & 0.92 & 0.97 & 0.98 \\
\hline 6 & 0.55 & 0.64 & 0.74 & 0.76 \\
\hline 8 & 0.34 & 0.40 & 0.57 & 0.58 \\
\hline
\end{tabular}

Fig. 10 Iso-local Nusselt number profile on the target plate 


\section{$3 \cdot 3$ 衝突噴流}

平面的な $C_{p w}$ 分布を明らかにするために, $y-z$ 断面における衝突平板上の壁面平均圧力係数の等值線図を図 $9(\mathrm{a})$ から（d）に示寸. 図では上から順に $L / D_{e}=4 ， 6 ， 8$ における測定結果を示している. オリフィス形状は図 7 と 同様である. $C_{p w 0}$ は $y=z=0$ 地点，つまり平板とオリフィスの中心線上の $C_{p w}$ を示しており，その值を表に示し た. 正三角形, 正方形オリフィスの場合, 等 $C_{p w}$ 線図は $L / D_{e}=4$ においてオリフィス形状を反転した形状となり, axis-switching 現象が起こったことが確認できた. 正三角形オリフィスでは, $L / D_{e}=8$ までオリフィス形状を逆転 した等 $C_{p w}$ 線図となったが，一方正方形オリフィスでは $L / D_{e}=8$ ではほぼ円形の等 $C_{p w}$ 線図となった. 正六角形 オリフィスでは axis-switching 現象を確認することはできず, 等 $C_{p w}$ 線図は円形オリフィスと同様な円形の分布と なった. これらの結果から正三角形オリフィスにおける axis-switching 現象は下流部において $C_{p w}$ 分布に顕著な影 響を与えることがわかった. 最大の壁面圧力係数 $C_{p w 0}$ に着目寸ると, $L / D_{e}$ が等しい場合は $n$ が増大寸るにつれ 大きくなり, オリフィス形状が等しい場合は下流へ行くほど $C_{p w 0}$ が小さくなっていることが確認できた.

平板上の $N u$ 分布を明らかにするために，y-z断面における等又セルト数線図を図 10 (a) から（d）に示す.オリフ イス形状, $L / D_{e}$ は図 9 と同様である. 最大 $N u$ 数 $N u_{0}$ は $C_{p w 0}$ と同様に $y=z=0$ 地点, つまり平板とオリフィスの中心線 上の $N u$ を示しており, その值を表に示した. $\left|y / D_{e}\right|,\left|z / D_{e}\right|<2$ における衝突噴流領域の等 $N u$ 線図の傾向は図 9 で示 した等 $C_{p w}$ 線図と同様の傾向を示した。一方，全てのオリフィス形状において，壁面噴流領域つまり $C_{p w}=0$ の等 $N u$ 線 図は $N u=125$ の線からわかるように, 円形オリフィスでの衝突噴流と同様な円形状となった. また円形オリフィスにお ける $N u_{0}$ の最大值は円形ノズルと同様に $L / D_{e}=8$ で得られたが，他の正多角形オリフィスでは $L / D_{e}=4$ で得られた. さらに，正三角形，正方形オリフィスにおける $L / D_{e}=4$ の $N u_{0}$ は， 円形オリフィスにおける $L / D_{e}=8$ の值と同 等以上であり, $n$ が小さくなるほど $N u_{0}$ は大きくなった.

\section{4. 結語}

噴流の流れ挙動と衝突熱伝達特性に及ぼす正多角形(正三角形，正方形，正五角形，正六角形)オリフィスの影 響について実験的に検証した。

- 正 $n$ 角形オリフィス $(n=3,4,6)$ を使用した自由噴流の流れ挙動を，水素気泡法により可視化し調査した結 果 axis-switching 現象が確認された. axis-switching 現象の 1 サイクル完了した位置は, 正多角形オリフィスの辺 の数 $n$ が大きくなるほど, オリフィス出口方向へ近づく.

・オリフィスと衝突平板間の距離が $L / D_{e}=2 \sim 8$ の場合, 等壁面平均圧力係数分布は $n$ が大きくなるほど上流側 で円形オリフィスと同じ同心円状の分布となり， $n$ が小さくなるほど下流まで axis-switching 現象後の分布形状 が維持される.

・ $L / D_{e}=4 \sim 8$ における衝突平板上の等ヌセルト数分布は, よどみ点近傍の衝突噴流領域において等壁面圧力係 数分布と同様な傾向を示し, $n$ が大きくなるほどより上流側で同心円状の分布となり,$n$ が小さくなるほど下流 まで axis-switching 現象後の分布形状が維持される. しかし, 壁面圧力係数 $C_{p w} \fallingdotseq 0$ である壁面噴流領域では 全ての正多角形オリフィスにおいて円形オリフィスの分布とほぼ同じ分布となった．また， 円形オリフィスに おける $L / D_{e}=8$ と同等以上の $N u_{0}$ が，正三角形，正方形オリフィスにおいて $L / D_{e}=4$ で得られた. このこと から, オリフィスと衝突平板間の距離に応じて, 最適な形状のオリフィスを使用することにより, より高い岐 点熱伝達を得ることができる可能性がある. また, $L / D_{e}=4$ では, $n$ が小さくなるほど $N u_{0}$ は大きくなっており, このとき同一断面の自由噴流軸線上の乱れ強さも, $n$ が小さくなるほど大きくなった.

\section{文献}

(1) G. N. Abramovich, The Theory of Turbulent Jets (1963), The M.I.T.Press.

(2) N. Rajaratnam, Turbulent Jets (1976), Elsevier Scientific Pub.

(3) 社河内敏彦, 噴流工学 (2004), 森北出版.

(4) P. Sforza and N. Trentacoste, "Further Experimental Results for Three-Dimensional Free Jets", AIAA Journal, Vol. 5,No. 5 (1967), pp. 885-891. 
(5) F. Hussain and H. Hussain, "Elliptic jets. Part 1. Characteristics of unexcited and excited jets", Journal of Fluid Mechanics, Vol. 208 (1989), pp. 257-320.

(6) K. B. M. Q. Zaman, “Axis Switching and Spreading of an Asymmetric Jet: the role of coherent structure dynamics”, Journal of Fluid Mechanics, Vol. 316 (1996), pp. 1-27.

(7) J. Mi, G. J. Nathan and R. E. Luxton, "Centreline Mixing Characteristics of Jets from Nine Differently Shaped Nozzles", Experiments in Fluids, Vol. 28 (2000), pp. 93-94.

（8）檜和田宗彦，三松順治，田中光三，親川兼勇，小寺剛史，広瀬信之，“音場励起を伴う楕円衝突噴流熱伝達: アスペク 卜比の影響”, 熱工学講演会講演論文集 (2001), pp. 441-442.

(9) W. R. Quinn, "Near-Field Measurements in a Equilateral Triangular Turbulent Freejet", AIAA Journal, Vol. 43, No. 12 (2005), pp. 2574-2585.

(10) M. Chaudhari, B. Puranik, A..Agrawal, "Effect of Orifice Shape in Synthetic Jet Based Impingement Cooling", Experimental Thermal and Fluid Science, Vol. 34, No. 2 (2010), pp. 246-256. 